\begin{abstract}
Aleš Vrbata, PhD.
State University of Feira de Santana

Literature and Cultural Diversity Post-Graduate Department

AVENIDA TRANSNORDESTINA S/N

Caixa Postal: $252-294$

CEP: 44.036-900

Feira de Santana

Brasil

alesvrbata@hotmail.com
\end{abstract}

\title{
Emil Višňovský: Richard Rorty a zrkadlo filozofie
}

Bratislava, Kalligram 2015, 360 s.

Na konci roka 2015 sa z pera slovenského filozofa Emila Višňovského dostala slovenskému čitatel'ovi do rúk kniha o diele a myslení jedného z najvýznamnejších a najoriginálnejších filozofov 20. storočia - Richardovi Rortym. Kniha, ako uvádza autor, je pozvaním k čítaniu Rortyho filozofie, ktorá je dnes príležitost'ou pre reflexiu súčasných aktuálnych a závažných tém: poznanie, hodnoty, l'udský život, morálka, politika, demokracia, náboženstvo, spoločnost', kultúra. Višňovský predstavuje Rortyho filozofiu ako neuzavretý spôsob myslenia práve o tých otázkach, ktoré sú pre človeka v súčasnom svete dôležité.

Autor recenzovanej monografie sa dlhodobo zaoberá filozofiou Richarda Rortyho, napísal viaceré významné práce o pragmatizme a neopragmatizme, je prekladatel'om textov pragmatickej proveniencie. Višňovský je aj zakladatel'om a predsedom Central European Pragmatist Forum. Jeho posledná monografia inšpiruje čitatel'a k tomu, aby sa kriticky pozrel na dedičstvo pragmatistov, umožňuje čitatel'ovi výbornú orientáciu a prehl'ad v Rortyho filozofii, a ukazuje ponor do meandrov filozofického myslenia 20. a 21. storočia.

V posledných rokoch je filozofia Richarda Rortyho v popredí záujmu svetovej filozofie, aj ked' v našom prostredí slovenskej filozofie sa tento záujem len prebúdza. „Naša domáca filozofia sa s Rortym doteraz ani len nestretla“ (s. 16 - 17). Preto $\mathrm{v}$ našom intelektuálnom priestore môžeme $s$ radost'ou uvítat', že práve na Slovensku vychádza rozsiahle a seriózne dielo o jednom z najoriginálnejších filozofov 20. storočia.

Višňovský chce vo svojej monografii ukázat', že pochopit’ filozofa znamená študovat' jeho dielo i život vo vzájomnej jednote, preto jeho zámerom je predstavit' slovenskému čitatel'ovi Rortyho filozofiu v ucelenejšej podobe. Rortyho diela predstavuje genealogicky tak, ako sa jeho názory postupne vyvíjali. Zobrazuje jeho intelektuálny vývoj, jednotlivé etapy a kl'účové témy jeho myslenia. Kapitoly knihy ukazujú ako Rortyho filozofia prechádzala fázami od raného cez zrelé po neskoré obdobie počas polstoročia jeho prítomnosti vo svetovej filozofii. Kniha je 
doplnená o bohatý poznámkový aparát, súhrnný zoznam všetkých Rortyho prác, zoznam prác preložených do slovenského a českého jazyka, sekundárnu literatúru a menný register.

V úvodnej časti Predhovor (s. 13 - 19) a Namiesto úvodu: Postmoderný filozof Richard Rorty? (s. 20 - 44) Višňovský zdôvodňuje motívy, ktoré ho viedli k napísaniu práce a vôbec tie, ktoré ho motivovali zaoberat' sa Rortyho filozofiou . Višňovského zaujal Rorty otázkami a odpoved'ami na ne: akú filozofiu rozvíjat'? Aká filozofia má zmysel a perspektívu? Ako filozofovat' inak, aby to niečo znamenalo? Na čo je dobrá filozofia a či je vôbec na niečo dobrá?

Višňovský t’ažisko Rortyho práce hl'adá v jeho úsilí zodpovedat' si otázku, čo je filozofia, čím by mohla byt'. Znamená to ukázat' súvislost' filozofie s l'udskými sociokultúrnymi praktikami a ukázat' jej l'udský zmysel. Filozofiu predstavuje ako l'udské zrkadlo alebo zrkadlo l'udskosti, pretože podl'a Rortyho je filozofia l'udská záležitost', s ciel'om ovplyvňovat' myslenie a konanie l'udí v každodenných situáciách, zvlášt' v tých kritických, v ktorých sa nachádza súčasné l'udstvo. Rorty podl'a Višňovského nastavil zrkadlo filozofii: kritické, imaginatívne, pragmatistické a metafilozofické. Rovnako nastavil filozofické zrkadlo l'udskému svetu a kultúre. Išlo mu o jej užitočnost' a relevantnost' pre život.

Višňovský sa vo svojej monografii podujal na nel'ahkú úlohu, v kontexte Rortyho filozofie ukázat', že metafilozoficky skúmat' filozofiu samu znamená skúmat' to, čo filozofi robia, ako to robia a prečo to robia, čo chcú svojou filozofickou činnost'ou dosiahnut'. Ked'že filozofická činnost' je reflexívna a sebareflexívna, metafilozofická sebareflexia by mala sprevádzat' každú filozofickú reflexiu v záujme toho, aby sme vo filozofii príliš nezablúdili a neodkláňali sa od jej zmyslu či ciel'a, ktorý sme si predtým formulovali. Je to otázka, ktorú Višňovský považuje aj za prvotnú otázku filozofie samej, t. j. otázka „kto sme my, l’udia?“ Kto sme my, l’udia, čo filozofujeme; my, čo si kladieme "filozofické otázky"? V Rortyho formulácii je to otázka „prečo v našej kultúre existuje fenomén filozofie?“ Rorty sa pokúsil opustit’ zastarané a prekonané spôsoby myslenia, pochopit’ historicitu samotnej filozofie a vydat' sa na cestu tvorivého hl'adania nových spôsobov filozofovania. Podáva odvážnu kritiku filozofie za to, že kladie zlé, vymyslené, nereálne a neužitočné otázky. Sú to výzvy na zmenu v orientácii i predmete, v metóde i štýle filozofie. Rortyho význam podl'a autora spočíva v pokuse o filozofickú revolúciu, ktorú chcel začat'.

Prvá kapitola Rané obdobie (1931 - 1979) (s. 45 - 129) je predstavením raného obdobia tvorby Rortyho až do vydania jeho práce Filozofia a zrkadlo prírody v roku 1979. Višňovský v nej opisuje dynamiku filozofického myslenia 20. storočia a situáciu l’udstva, na ktorú Rorty reaguje svojim dielom, pričom jeho základná intencia bola podl'a Višňovského terapeutická a metafilozofická. Išlo mu o hl'adanie zdrojov a predpokladov filozofických problémov, ale aj o zdôvodnenie toho, 
že povaha filozofie je imaginatívna, kreatívna, „filozofia má pozdvihovat' l'udského ducha a hl'adat' pre neho nové možnosti a formy života, klást' novým spôsobom relevantné otázky a vymenit' kantovské otázky za Deweyovské: „Na akých spoločenských ciel'och sa budeme podiel'at'? Akým človekom by som sa najradšej stal? (s. 49)

Višňovský v tejto kapitole predkladá pred slovenského čitatel'a vel'mi cenný prehl'ad súčasnej americkej filozofie a pragmatizmu, hl'adá korene americkej filozofie, či americkej filozofickej tradície, v ktorej Rorty zanechal nezmazatel'nú stopu. Kladie si otázku do akých smerov svetovej filozofie je možné Rortyho zaradit'. Na otázku, či bol Rorty postmoderný filozof neexistuje podl'a Višňovského jednoznačná odpoved', pretože rámec postmodernizmu je mu priúzky (s. 39). Višňovský ukazuje, že Rortyho spôsob filozofovania bol od začiatku modifikovaný jeho metafilozofickým prístupom, ktorý hl’adal komparácie, inovácie a konverzácie medzi rôznymi školami myslenia, najskôr s pragmatizmom, neskôr s kontinentálnou filozofiou (Nietzsche, Heidegger, Sartre, Foucault, Derrida, Habermas). Typickým postmodernistom podl'a autora nikdy nebol a jeho filozofický vývoj pokračoval v rámci postanalytickej filozofie a neopragmatizmu. Rorty bol podla neho postmoderný pragmatista, ale jeho intencia bola nietzscheovská: kriticky mysliet’ až ku koreňom západnej filozofie. Rorty sa tiež snažil o dôsledný anti-platonizmus, ako kritiku binarity skutočnosti a poznania na "pravé" a „nepravé“ („vyššie“ a „nižšie“), čo vo filozofii znamenalo vydat' sa na cestu hl'adania neutrálnych, ahistorických, objektívnych kritérií. To však podl'a Rortyho nie je možné, pretože nikto sa nemôže vymanit' zo svojej doby a vyviazat' sa z kontextu vlastnej komunity. Žiadna filozofia nemôže byt' bezpredpokladová.

Rortyho filozofická identita bola podl'a Višňovského bazálne pragmatistická (James a Dewey), no to mu nebránilo inovovat' pragmatizmus lingvistickou (neskorý Wittgenstein), resp. postanalytickou filozofiou (Quine, Sellars, Davidson). Časti tejto filozofie však vyčítal abstraktné, dehumanizujúce, scientistické chápanie jazyka. Jeho „postlingvistický neopragmatizmus“ mu však nebránil inšpirovat' sa aj kontinentálnou filozofiou od Nietzscheho cez Heideggera po Derridu (no selektívne aj d'alšími: Kierkegaardom, Freudom, Sartrom, Foucaultom a i.). Višňovský zdôrazňuje jedinečnost' Rortyho filozofickej pozície vo svetovej filozofii. Na jednej strane bol americký pragmatista, ale v domácom kontexte aj analytický a postanalytický filozof. Na druhej strane vynikajúci znalec európskej filozofie. Bol tiež ten, kto toto všetko spojil do svojho „rortyizmu“ - filozofie, ktorá sa rozvíjala v troch líniách:

1. v línii lingvistickej filozofie smerom k neopragmatizmu;

2. v línii neopragmatizmu smerom $\mathrm{k}$ európskemu postmodernizmu;

3. v línii európského postmodernizmu smerom k postlingvistickej filozofii a postpragmatizmu. 
Višňovský si myslí, že Rorty stavia mosty medzi troma filozofickými stranami: lingvistickou (post-analytickou) filozofiou, pragmatizmom a kontinentálnou (postmodernou) filozofiou.

Druhá kapitola s názvom Zrelé obdobie (1979 - 1998) predstavuje Rortyho obdobie života a tvorby od roku 1979 až po vydanie 3. zväzku filozofických spisov Pravda a pokrok v roku 1998 (s. 131 - 243). Na ceste poznávania Rortyho diela, Višňovský ukazuje čitatel'ovi postupné filozofické dozrievanie Rortyho, od lingvistického obratu k pragmatizmu. Rortyho zameranie vo filozofii bolo podla autora primárne metafilozofické, „terapeutické“: filozofia má klást' otázky o vlastných otázkach a byt’ zmysluplnou konverzáciou o nich. Filozofia je slobodná kreatívna intelektuálna činnost', ktorej podobu určujú len filozofi sami. Budúca filozofia preto nemusí mat' podobu, akú mala filozofia v minulosti. Rortymu išlo o to, aby filozofia bola zaujímavejšia, relevantnejšia a užitočnejšia pre l'udí, spoločnost' a kultúru.

Základný Rortyho postoj je v tejto kapitole deklarovaný v kontexte tvrdenia, že žiadna filozofia nie je bezpredpokladová, ako to v „zrelej“ formulácii vyjadril v predslove k svojmu dielu Filozofia a zrkadlo prírody: „Hned’ na začiatku štúdia filozofie ma zaujalo, ako sa v dôsledku nových predpokladov objavujú nové filozofické problémy, ako zanikajú či ako menia svoju podobu... že totiž „filozofický problém“ je výsledkom podvedomého prijatia predpokladov zabudovaných v jazyku, v ktorom bol problém sformulovaný; a tieto predpoklady treba preskúmat' ešte skôr, než začneme brat’ vážne samotný problém“" (Rorty 1979/2000).

Rorty sa snaží nájst' cestu z vnútornej uzavretosti filozofie do seba samej, pretože filozofi konverzujú, diskutujú len sami medzi sebou. Ako je možná budúcnost' filozofie tak, aby nekopírovala svoju minulost'? (s. 208) Rorty vyjadruje názor, že „produktom filozofie môže byt’ len dialóg, nie nejaká vec, technika alebo niečo podobné ako vo vede, či ako obraz v umení. Vo filozofii nemôžeme z tohto dialógu nikdy a nijako vystúpit', neustále ho „produkujeme“ a „reprodukujeme“. Každý filozof k nemu prispieva a je zodpovedný za to, ako a čím. Len tak žije filozofia ako oblast' kultúry; len vtedy je živá ako činnost'. Inak povedané, filozofia „žije“ vtedy (a dovtedy), kým je živý filozofický dialóg, lenže v tom lepšom prípade nie iba medzi filozofmi samými“ (s. 101). Osamelý, izolovaný, do seba uzavretý, filozof sa z tohto pohl'adu javí ako nešt'astná karikatúra filozofa (s. 102). Rorty sa usiluje o kritickú relexiu z vlastnej vykryštalizovanej pozície, takže s ostatnými filozomi a filozofiami vstupuje do kompetentnej konverzácie (s. 232). Rola filozofie by mala byt' sociálna a globálna (s. 237). Za hlavnú sociálnu funkciu filozofie Rorty považuje: „terapiu v zmysle zbavovania sa zastaraných myšlienok a spôsobov myslenia. „Filozofickú terapiu“ preňho robili najmä traja filozofi - 
Wittgenstein, Heidegger a Dewey - tým, že prehodnocovali to, čo robili filozofi pred nimi“ (s. 207). Historicita filozofie je podl'a neho vyjadrením kreativity, inovácie, vývoja, pretože ukazuje, že celé filozofické diskurzy sú „historické pokusy o riešenie historických problémov kultúry a civilizácie, nie večné a nemenné paradigmy (s. 133).

Višňovský predstavil klúčové momenty Rortyho metafilozofie, ktorá nastavuje odvážne, provokatívne, ale hlboko premyslené „zrkadlo“ celej západnej filozofii od Platóna cez Descarta a Kanta až po súčasnost'. Po Rortyho analýzach modernej západnej kultúry, úvahách o racionalite a kultúrnom poriadku si podl'a Višňovského jasne uvedomuje, že „filozofia musí investovat' svoj potenciál do riešenia „problémov l'udí“, a nie „problémov filozofov“ (s. 242).

Tretia, posledná kapitola (s. 245 - 311) s názvom Neskoré obdobie (1998 2007) je reflexiou Rortyho tvorby v posledných rokoch života od roku 1998 (napr. Pozdvihnutie našej krajiny; Filozofia a sociálna nádej; Demokracia a fiozofia; Kontingencia, irónia a solidarita) po vydanie 4. zväzku filozofických spisov s názvom Filozofia ako kultúrna politika (2007) a zároveň otvára nové možnosti interpretácie Rortyho filozofie. Višňovský v nej zretel'ne ukazuje kontinuitu Rortyho myslenia, postupné napíňanie pôvodného zámeru Rortyho, s ktorým sa vydal na cestu od platónskeho absolutizmu k rortyovskému antiabsolutizmu (s. 89), vyjadrenia toho, „čo by mali filozofi robit', aby boli užitoční pre l'udské spoločenstvo i pre svoj vlastný život" (s. 89) a tiež to, kým sa v poslednej dekáde svojho života stal: politickým, morálnym a kultúrnym filozofom. Rorty sa v tomto období zaoberal najmä otázkou slobody a pravdy, filozofiu chápal ako kultúrnu politiku (s. 284 - 311). Najdôležitejšou možnost'ou bola pre Rortyho sociálna nádej pre l'udstvo, ktorá podl'a Višňovského je jedným z centrálnych pojmov Rortyho politickej filozofie (s. 278).

Ked' Višňovský uvažuje o vývoji Rortyho filozofie, identifikuje základnú rolu filozofie z hl'adiska otázky: na čo je dobrá? Višňovský sa sústred'uje na poukázanie súvislosti filozofie s l'udskými sociokulútrnymi praktikami, ked' na základe brilantnej analýzy Rortyho diela, ukazuje jej l’udský zmysel a chápe filozofiu v kontexte každodenného života. Znamená to podl'a neho zmenit' nielen tému a orientáciu filozofie, ale aj spôsob myslenia vo filozofii. Znamená to vzdat' sa platónskych chimér, ktoré nikdy nemôžeme dosiahnut' a uvedomit' si, „kto filozofuje“, teda kto sme my l'udia, čo filozofujeme. Filozofia sa má rozvíjat' ako pokračovanie zdravého rozumu a používanie prirodzeného jazyka, a nie vytváranie vedeckého rozumu a umelého formalizovaného jazyka. Višňovský prenikavo odhal'uje, že v pozadí Rortyho celoživotnej tvorby, je metafilozofické východisko, že filozofia je l'udská záležitost', jedna z našich intelektuálnych, lingvistických sociokultúrnych praktík, ktoré sme si vytvorili. Filozofi by mali byt' „sol'ou kultúry“ či jej „korením“ (s. 312). 
Višňovského monografia je v našom intelektuálnom prostredí nielen dôstojným doplnením chýbajúceho diela z významnej oblasti svetového filozofického myslenia. Vzhl'adom na premyslene zostavený text, prenikavý filozofický pohl'ad a erudovanost' Višňovského, má čítanie a pochopenie Rortyho ambíciu stat' sa tým, čo proklamuje sám autor: zmenou nášho pohl’adu na svet (s. 316).

\section{Literatúra}

RORTY, R. (1979/2000): Filozofia a zrkadlo prírody. Bratislava: Kalligram.

\section{Doc. Mgr. Andrea Javorská, PhD.}

Univerzita Konštantína Filozofa

Filozofická fakulta

Katedra filozofie

Hodžova 1

94974 Nitra

Slovenská republika

ajavorska@ukf.sk 